\title{
Saints and Tradition in Coptic Orthodox Christianity in Egypt
}

\author{
MARKÉTA ŠEBELOVÁ*
}

Today, in the Western and especially so in the Central European imagination, the Middle East stands for Arabs and these are consequently conflated with Islam. Yet, as Talal Asad points out, it is worth remembering that the Middle East is the cradle of Judaism and Christianity as well as of Islam ${ }^{1}$ and thus the idea of Europe being associated only with Christianity and of the Middle East only with Islam is misleading. Asad argues that such a conceptualization marginalizes Eastern Christianity (and Sephardic Judaism), situating them as minor branches of Christianity (and of Judaism) as they are located on the periphery of our imagination of Christian space. ${ }^{2}$ In similar vein, Tom Boylston and Chris Hann observe that the anthropology of Christianity has been focused on studying Protestantism and Pentecostalism, making Orthodox Christianity (particularly Middle Eastern Christianity) challenging to place within conversations in the anthropology of Christianity. ${ }^{3}$ Boylston further draws attention to the fact that anthropologists of Christianity incline to recognize the dominant problem of Christianity in Hegelian terms - that is, as "the difficulty of making the divine present in a fallen world" or accessing the divine. ${ }^{4}$ Such difficulty does not arise for Boylston's research subjects, Ethiopian Orthodox Christians, as it does not for mine, Coptic Orthodox

* ORCID: 0000-0002-1776-677X. I would like to thank Michaela Ondrašinová and all my anonymous reviewers for their most beneficial and constructive comments; they enhanced my work greatly. Special thanks go to the English language editor.

1 Thus, Arabs are not only Muslims but can be and are Jews and Christians.

2 Talal Asad, The Idea of an Anthropology of Islam, (Occasional Papers Series), Washington, DC: Center for Contemporary Arab Studies - Georgetown University 1986.

3 Tom Boylston, The Stranger at the Feast: Prohibition and Mediation in an Ethiopian Orthodox Christian Community, Oakland, CA: University of California Press 2018, 4; Chris Hann, "The Anthropology of Christianity Per Se", European Journal of Sociology 48/3, 2007, 383-410.

4 T. Boylston, The Stranger at the Feast..., 4.

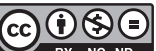

Religio: Revue pro religionistiku 29/1, 2021, 3-32.

https://doi.org/10.5817/Rel2021-1-1

This work can be used in accordance with the Creative Commons BY-NC-ND 4.0 International license terms and conditions (https://creativecommons.org/licenses/by-nc-nd/4.0/). 
Christians in Egypt, whose experience with the divine is a subject of this article. More specifically, I examine and show their relationship towards saints and the way saints and their lives are positioned as exemplars which Orthodox Copts through various venues (such as Sunday Schools, sermons, miraculous narratives) are directed to follow. Similarly to Andreas Bandak's argument in his "Exemplary Series and Christian Typology: Modelling on Sainthood in Damascus", 5 Orthodox Copts, too, model their selves on narratives about their saints, and the saints' lives are, likewise, turned into forma vitae, i.e., lives to be emulated. This falls squarely within the reasoning proposed by Joel Robbins, who contends that "values exist in the form of socially concrete enacted examples" and that "values are ideas that motivate action". 6 In the Coptic Orthodox context, saints, then, embody Coptic Orthodox values, which are socially accessible through ecclesiastical teachings on the appropriate Coptic Orthodox Self. As Bandak highlights, during sermons (or in other settings), saints positioned as models are presented in a series where listeners are put into the center of the story and are made a part of the same series as the saints, which then "allows the listeners to see themselves reflected and challenged to become part of the same series". 7 This seriation, as he calls it, authorizes certain social actions, and social agency is thus challenged to follow such comportment (and consequently particular social values).

Additionally, I want to illustrate how the Coptic Orthodox Church uses its theological concept of tradition to relate to its past. Put differently, through an ethnographic portrait of the position that saints have in Coptic Orthodox Christianity, I want to explore how this relationship between Copts, their saints, and the way saints are situated within Coptic Orthodox Christianity is reflected in the Copts' relationship towards their past. Through a discussion of Father Malaty's work on tradition, ${ }^{8}$ I argue that the Orthodox theological concept of tradition is integral to Orthodox faith and that, in this context, saints are essential not only as integral parts in the

5 Andreas Bandak, "Exemplary Series and Christian Typology: Modelling on Sainthood in Damascus", Journal of the Royal Anthropological Institute 21/S1, 2015, 47-63: 48.

6 Joel Robbins, "Ritual, Value and Example: On the Perfection of Cultural Representations", Journal of the Royal Anthropological Institute 21/S1, 2015, 18-29: 18-19.

7 A. Bandak, "Exemplary Series and Christian Typology...", 52.

8 For a Coptic Orthodox interpretation of the notion of tradition, I rely extensively on Father Malaty's discussion on the subject in Tadros Y. Malaty, Tradition and Orthodoxy, Sporting - Alexandria: St. George Coptic Church 1979. Berit Thorbjørnsrud in her book describes Father Malaty as: “... without a doubt today's the most prolific and influential Coptic theological interpreter of Coptic history" (Berit Thorbjørnsrud, Controlling the Body to Liberate the Soul: Towards an Analysis of the Coptic Orthodox Concept of the Body, Oslo: Unipub forlag/Akademika AS 1999, 67, note 1). 
seriation described above but also because they represent links in the tradition and are indispensable in transmitting that tradition.

Such a perception of the past serves as a connecting point with the anthropology of "Pentecostal" Christianity - in particular, with Simon Coleman's argument in his "'Right Now!': Historiopraxy and the Embodiment of Charismatic Temporalities". He points out that charismatic Christianity (or any charismatic practice) involves conceiving of (and indeed making) history in specific ways and introduces the term "historiopraxy" connoting a process in which "believers attempt to "perform' the relationship between the past and the present (and the future) in a productive sense, not only through narrative accounts but also through embodied forms of worship and mission". "Throughout the article I will elaborate with ethnographic evidence on a production of time which connects agency and temporality, as it involves the understanding and/or perception of the transformation of the Self (and its agency) when undergoing a charismatic event (e.g., a miracle) and re-living this event as one which can be found in the Orthodox past. The relevance of Coleman's argument to a Coptic Orthodox setting resides in miraculous discourse, which is intricately interwoven with saints. An encounter with the miraculous and a feeling of close attachment to a saint enable a believing Copt to experience the world in the same way as the saint did and re-live the past. The performative aspect which Coleman emphasizes is fully brought to life among Copts especially thanks to the concept of tradition sketched above.

Thus, in the following pages, I will 1) provide an ethnographic sketch of Coptic Orthodox saints as it emerged from my ethnographic fieldwork from 2001-2003; ${ }^{10}$ 2) show how, through example- and exemplar-making, they are made relevant to contemporary Copts and how the miraculous constitutes an important aspect of saints; and 3) illustrate their relationship to the Orthodox disposition to the past with implications for experiencing the divine.

9 Simon Coleman, "Right Now!': Historiopraxy and the Embodiment of Christian Temporalities", Ethnos 76/4, 2011, 426-447: 434.

10 The fieldwork was conducted during my studies at The American University in Cairo, mainly in various districts of Cairo, but also in Upper Egypt and Middle Egypt. Here, I would like to note my firm belief that theoretical approaches need to be woven into ethnography and that these perspectives need to be applied directly to practices or events occurring to specific individuals in cultural-historical circumstances. This conviction is reflected in using my informants' chosen pseudonyms whenever they speak and including bits and pieces about them in a footnote in order to convey, however partially and incompletely, who they were. 


\section{Context}

Situated among a much larger Muslim population, Orthodox Copts in Egypt feel intensely discriminated against and threatened, perceive themselves as a population indigenous to Egypt, claiming to be the descendants of the ancient Egyptians. ${ }^{11}$ Accordingly, generally speaking, religious identity supersedes any other social status especially when dealing with a person of a different faith (be it Muslim or a different Christian denomination). Saints (and by extension miracles), in this context, represent a useful way to glimpse the constitution of religious identity and indeed personal identity since saints and their miracles are perceived as distinctly Orthodox Coptic, exclusively "belonging" to Orthodox Copts and distinguishing them from both Muslim and other Christian populations. ${ }^{12}$ The space allocated here bars an in-depth historical account of the relations between Copts, Muslims, and others. However, excellent elaborations on the history of these relations are provided by several authors, the most recent and in my view most notable being the brilliant work of Angie Heo The Political Lives of Saints, but equally interesting is the work of Brigitte Voile in her Les Copts d'Egypte sous Nasser: Sainteté, miracles, apparitions, Anthony Shenoda's PhD dissertation Cultivating Mystery: Miracles and a Coptic Moral Imaginary and Berit Thorbjørnsrud's Controlling the Body to Liberate the Soul, each author, albeit from a different angle, providing a detailed historical development of the Coptic Church and the way Coptic identity has been construed. ${ }^{13}$

\section{Introducing the saints}

Similarly to Tom Boylston's observation about the position of saints in the Ethiopian Orthodox Church, saints are central figures playing a fundamental mediating role in Coptic Orthodox Christianity. ${ }^{14}$ They are asked

11 See for instance Angie Heo, The Political Lives of Saints, Oakland, CA: University of California Press 2018, 77-78; Anthony Shenoda, Cultivating Mystery: Miracles and a Coptic Moral Imaginary [manuscript of a $\mathrm{PhD}$ thesis], Cambridge: Harvard University 2010, 16, or B. Thorbjørnsrud, Controlling the Body to Liberate..., 69-74.

12 See Markéta Šebelová, "The Miraculous and Coptic Orthodox Christianity in Egypt: Power Relations in Operation", Religio: Revue pro religionistiku 27/2, 2019, 221-246.

13 See A. Heo, The Political Lives of Saints...; Brigitte Voile, Les Copts d'Egypte sous Nasser: Sainteté, miracles, apparitions [online], Paris: CNRS Éditions 2004, $<$ https://books.openedition.org/editionscnrs/2480?lang=en>, [31 March 2021]; A. Shenoda, Cultivating Mystery..., and B. Thorbjørnsrud, Controlling the Body to Liberate...

14 T. Boylston, The Stranger at the Feast..., see also, for instance, A. Heo, The Political Lives of Saints...; A. Shenoda, Cultivating Mystery...; Otto F. A. Meinardus, Coptic Saints and Pilgrimages, Cairo: The American University in Cairo Press 2002; 
to intercede on behalf of the Coptic Orthodox community during the Holy Mass, and throughout the liturgy various saints are mentioned several times. ${ }^{15}$ As Father Malaty points out, the intercession of saints is a crucial Coptic Orthodox theological notion:

In brief, the intercession of Saints in our Orthodox concept confirms the effectiveness of the saving deeds of God in the life of every believer, and substantially rejects any ideas of worshipping Saints. It declares the unity of the Church, as members of one body, all members suffering if one is hurt, and pleased at the honor of others $(1 \mathrm{Cor}$. $12: 26,27){ }^{16}$

In addition, a specific part of the liturgy is devoted to a reading from the Synaxarium, a compilation of 381 saints' lives, where each day of the year is assigned to a saint according to his/her ascension into Heaven on that day. ${ }^{17}$ Saints and their lives are intricately intertwined with any Coptic believer's perception of Coptic Orthodox Christianity, a view consciously reinforced and built upon by the Church. Yet, the category of saints in the Coptic Orthodox Christianity is not an enclosed, clearly defined domain but rather a fluid one ${ }^{18}$ as often times people who are known to have the ability to perform miracles or show particular transcendental qualities ${ }^{19}$

B. Thorbjørnsrud, Controlling the Body to Liberate...; Nelly van Doorn, "The Importance of Greeting the Saints: The Appreciation of the Coptic Art by Laymen and Clergy", in: Hans Hondelink (ed.), Coptic Art and Culture, Cairo: Netherlands Institute for Archaeology and Arabic Studies in Cairo - Shouhdy Publishing House 1990, 101118.

15 Saints are asked for intercession during the St. Basil liturgy in the following order: St. Mary, the Heavenly Hosts, Archangel Michael, the Apostles, St. Mark (separately, because he is the patron and founding Apostle of the Coptic Orthodox Church and its First Pope), St. George, St. Mina, Saints of the day ("through the prayers of all the Saints of this day, each one in his name, O' Lord, grant us the forgiveness of our sins"), and the current Patriarch (Orthodox Eastern Church, The Divine Liturgy of St. Basil the Great, trans. David Frost, Sydney: Aquila Books 1998, 34-37). The Coptic Orthodox Church uses three liturgies: St. Basil's, St. Gregory's and St. Cyril's I with St. Basil liturgy used most of the year.

16 Tadros Y. Malaty, St. Mary in the Orthodox Concept, Sporting - Alexandria: St. George Coptic Church 1978, 63.

17 According to Jill Kamil, Christianity in the Land of the Pharaohs, Cairo: The American University in Cairo Press 2002, 272, the Coptic Synaxarium developed from a local martyrology, to which other Christian saints were added and its compilation began sometime during the fourth and fifth centuries.

18 Likewise, O. F. A. Meinardus, Coptic Saints and Pilgrimages..., 1, points out the ambivalence of the term "saint". According to him, over time the term acquired various meanings, and underwent many changes.

19 These qualities (or gifts as they are called) are generally interpreted as signs of saintliness and include the designation of a person as a sa'eh (traveler) and/or possession of shafafeya body. Sa'eh are people who can (or could) transfer themselves from place to place in a matter of seconds, in anthropological terms it would be astral projection (i.e., 
are frequently considered and venerated as "saints" although they have not been recognized as such (yet) by the Church and/or are still alive. An example of such a saint would be the late Pope Kyrillos VI, who is revered (as he is believed to perform many miracles) and has been referred to as a saint. However, since he died only in 1971, he was not yet canonized at the time of my fieldwork, although there was little doubt at that time that eventually he would be.

Officially the Coptic Orthodox Church can canonize a person as a saint fifty years after his/her death, and pertinently to this discussion, the canonization does not depend on a person's performance of miracles. The lay explanation of the rationale for the waiting period, which I collected, is to ensure that there are indeed miracles coming from the "saint-to-be" and that those who knew the "saint-to-be" will die as well and thus will not confuse fond memories for miracles. Notice again the position of miracles, although the miraculous is completely irrelevant for canonization, it is perceived (by lay persons) as significant. ${ }^{20}$

In addition, there are individuals recognized as "living saints" although sometimes people feel restrained to praise such a "living saint" too much, offering assurance that "we will hear many more miracles coming from him after his death". ${ }^{21}$ There are various reasons cited for this limitation - the humbleness of the person, or the possibility of being overheard by the devil, who would consequently tempt the "living saint" (the fall of such

the ability to travel outside the body). The late Pope Kyrillos VI, or late Mother Irini from Abu Saifein convent, are said to have been sa'eh. Shafafeya body means knowing things in advance without being told, i.e., clairvoyance (not to be confused with telepathy, as my research participants stressed). For example, knowing the name of a person without being told is shafafeya. Heo aptly terms it "'second sight,' the capacity to see a person's past and future" and she reports that priests able to exorcise evil spirits are also often bestowed with this quality (A. Heo, The Political Lives of Saints..., 157158). In terms of holiness, although this is not specified by the Church, the qualities of sa'eh and shafafeya imply a higher degree of one's spirituality/sanctity.

20 At the same time, history shows that socio-political context enters the debate and that the rule of a waiting period of fifty years is not always followed. For example, Angie Heo reports that people who died in a 2011 car bomb attack in Two Saints church in Alexandria on January 1, 2011 were declared martyrs (a category of saints) the following day, i.e., on January 2, 2011 (A. Heo, The Political Lives of Saints..., 60). Likewise, the late Pope Kyrillos IV was canonized in June 2013, i.e., only forty-two years after his death. Furthermore, who is (or is not) conferred the status of martyr depends in reality on other factors than "only" on dying for Jesus Christ. Thus, people dying at Tahrir Square during 2012 are officially by the Church called martyrs while Copts killed in the Maspero Massacre are not. For a thorough description, see A. Heo, The Political Lives of Saints...

21 In this instance, we were talking about now late H. H. Pope Shenouda III, who at the time was the Head of the Church but I heard many similar remarks about other people too. 
a person is much more valued by the devil than the fall of an "ordinary person"). In this context, it does not appear meaningful to reserve the term "saints" for "the very special dead" as Peter Brown in his book The Cult of the Saints coined it, ${ }^{22}$ as there are, if I may paraphrase him, many "very special living" as well and accordingly more clarification and elaboration of the category of saints and their relationship to the miraculous is essential.

Coptic Orthodox saints constitute a heterogeneous realm with a degree of hierarchy among them based on the degree of holiness. Saints who declare their faith openly and without fear of repercussion, and who do not die because of their Christian faith, are titled "confessioners". ${ }^{23}$ This category of saints is situated below the category of "martyrs", who constitute theologically the most important and the holiest category of saints. The late H. H. Pope Shenouda notes on martyrs and the suffering associated with martyrdom:

... and so suffering for the Lord becomes a measure of the glory that awaits the faithful in the eternal Kingdom. Therefore, the Church places the martyrs above all the Saints. They are mentioned in the Church's prayers before the spirit-borne and the solitary fathers, who filled the wilderness with prayers and contemplation. They are also mentioned before our fathers the Patriarchs and Bishops, with all their services in spreading the Word. This is all because of the suffering they endured for the sake of God. ${ }^{24}$

Generally speaking, what differentiates any martyr from any other saint is his/her suffering for the sake of Jesus Christ. Every account of a martyr's life that I came across specifies in gruesome detail all the martyr's suffering ${ }^{25}$ as well as the persecution of other Christians in his/her time. In

22 Peter Brown, The Cult of the Saints: Its Rise and Function in Latin Christianity, Chicago: The University of Chicago Press 1981, 70.

23 This claim is based on the data collected from my fieldwork and on what my informants suggested. Alternatively, Berit Thorbjørnsrud refers to my category of confessioners as "martyrs of conscience" (also as "white" or "green martyrs") and she highlights the importance of sacrificing one's life for Christ (B. Thorbjørnsrud, Controlling the Body to Liberate..., 88).

24 H. H. Pope Shenouda III, Words of Spiritual Benefit II: 51-100, trans. Heshmat Kamal, Cairo: Dar El Tebaa El Kawmia - Coptic Orthodox Patriarchate 1998, 103.

25 Consider, for example, the following extract taken from the very beginning (!) of St. George's martyrdom: "King Dadianos ordered his men to unclothe George, bind a wrapper around his loins, raise him on the press and squeeze his body. The men carried out the King's orders till George's bones were crushed. Blood flowed from his sacred body and ran on the earth. The Saint endured the torments with bravery. Then the King ordered his men to bring shoes made of iron to be nailed to the Saint's feet. He also ordered them to lay the Saint stretched on his back and to hammer 600 pins into his abdomen. The Saint bore these pains patiently because the Lord strengthened his soul ..." (Bishop Mettaos, History and the Biographies of the Great Martyrs, St. George the Roman and St. George of Alexandria, trans. Aziz Kharbawi, Cairo: The 
other words, a martyr is a person willingly dying for his/her Christian faith. The reason martyrs are accorded prominence and are positioned as the holiest among all saints is the martyr's endurance of suffering for Jesus Christ. In my fieldwork, I have not encountered any hagiography about any martyr that would not include a thorough depiction of his/her suffering. Likewise, Heo notes that accounts of martyrs' lives missing details of his/her torture could not be considered authentic. ${ }^{26}$ In particular, she comments on Coptic films about the lives of the saints showing in chilling and meticulous manner the tortures which the saints/martyrs endured. She points out that the director Tawfik focuses on portraying God's power through the miraculous healings while slowly and carefully detailing all the trials and torments. ${ }^{27}$ In this context, it is perhaps noteworthy that these details of torture are understood by the viewers literally not metaphorically.

Thorbjørnsrud notes the importance of the sincerity of dying as a Christian, i.e., not attempting to be spared by denying Christ. In the clashes at the turn of the second millennium many Copts died because of their religion, and as such they are considered general martyrs and prayed for during the Holy Mass. However, she reports that since it is uncertain whether they sought to save their lives by denouncing Christ at the last moment, they are not classified as martyrs "equivalent to the ancient martyrs". ${ }^{28}$ At the time of my fieldwork (2001-2003), their classification was still distinct from the martyrs dying during the late Roman Empire, as my research participants expressed uncertainty whether the "new" martyrs sought to save their lives by denouncing Christ at the last moment, and thus they could not be classified as true martyrs. Otto Meinardus states that Copts who were martyred during Islamic dynasties are termed "new martyrs" and similarly, Angie Heo refers to Copts dying during Islamic rule as "neomartyrs". ${ }^{29}$ The attitude towards and earnestness of martyrdom is

convent of St. George 1995, 45). The detailed description of St. George's sufferings, conversion of people (due to his endurance of the suffering) and his three deaths continue for another twenty-five pages.

26 A. Heo, The Political Lives of Saints..., 43.

27 See ibid., 56.

28 B. Thorbjørnsrud, Controlling the Body to Liberate..., 89, note 1.

29 See O. F. A. Meinardus, Coptic Saints and Pilgrimages..., 27, and A. Heo, The Political Lives of Saints..., 37. In my fieldwork, I have not encountered either term; however, there has always been a difference between martyrs dying in the late Roman Empire (during the so-called "Era of the Martyrs" - see below) and martyrs dying later. And, again, we can notice the fluidity of the terms, as people who died in a 2011 car bomb attack were titled by the Orthodox Church as the "Two Saints' Martyrs" (see A. Heo, The Political Lives of Saints..., 60). 
profoundly meaningful in Coptic Orthodox Christianity and can be derived from the following quote:

Our fathers the martyrs, received martyrdom, not only with bearing and satisfaction, but even more with joy. Thousands of believers went from Damanhour to Alexandria to be martyrized, singing all the way hymns of joy. ${ }^{30}$

Further down in the same text, the late H. H. Pope Shenouda specifies martyrdom as the shortest way leading to Heaven, and only hours or moments away from joining the community of saints and enjoying the company of the fathers Abraham, Isaac and Jacob. Martyrdom is positioned as a fellowship in Christ's suffering (Phil 3:10) and hence "fellowship with Him in His death, and so fellowship with Him in His glory". ${ }^{31}$ Through martyrdom, a person can express his/her love towards Jesus Christ and the true value of his/her faith. In addition, the late H. H. Pope Shenouda provides yet another reason for the joy of martyrdom:

They loved martyrdom, because they knew that they were strangers in this world, and they loved eternal life with all their hearts. They did not see in death anything but release from the imprisonment of the body. ${ }^{32}$

Thorbjørnsrud argues that "true martyrs embody what the Copts consider are the finest Christian ideals - those that they themselves would like to realize". ${ }^{33}$ However, she also mentions people's uncertainty of being able to bear the amount of pain and suffering martyrdom is associated with.

In fact, I argue that suffering and pain constitute crucial notions in the Coptic perception of the surrounding reality. This attitude toward suffering and persecution has always been present in the Coptic Orthodox Church, as, significantly, the Church bases its calendar on martyrs, Anno Martyrii, ${ }^{34}$ commencing on August 29, 284 CE (Julian calendar), a day, when Diocletian became the Roman Emperor, whose rule is identified as a time of extraordinarily bloody persecution. Although Diocletian's persecution of Christians in Egypt only lasted for two years (303-305 CE), this period,

30 H. H. Pope Shenouda III, Words of Spiritual Benefit IV: 151-200, trans. Hesmat Kamal, Cairo: Dar El Tebaa El Kawmia - Coptic Orthodox Patriarchate 1998, 31.

31 Ibid., 32.

32 Ibid.

33 B. Thorbjørnsrud, Controlling the Body to Liberate..., 305.

34 There seem to be two Latin terms designating the Coptic Orthodox Calendar - either Anno Martyrii (of the Martyrs), which I collected, or Anno Martyrum. In any case, Christian Cannuyer, Coptic Egypt: The Christians of the Nile, trans. Sophie Hawkes, London: Thames and Hudson 2001, submits that the Coptic calendar consists of 13 months -12 months 30 days long, and an intercalary Little Month of 5 days at the end of the year, or 6 days in a leap year. 
now called the "Era of Martyrs", was long enough to provide the majority of the martyrs of the Coptic Church. Church historians (cited by Otto Meinardus) estimate the number of martyrs as ranging from 144,000 to $800,000 .{ }^{35}$ In other words, what I argue here is that in the Coptic Orthodox Church, suffering and persecution have been historically constituted as a meaningful way of representing the Copt's relationship to the surrounding reality.

In the framework of symbolic anthropology, Coptic Orthodox saints can be considered "key symbols" and, more particularly, suffering/persecution $^{36}$ can be perceived as representing a "root metaphor" and saints' lives as constituting "key scenarios". 37 The concept of a root metaphor was first suggested by Stephen Pepper (1942), who defined it in the following way:

A man desiring to understand the world looks about for a clue to its comprehension. He pitches upon some area of common-sense fact and tries if he cannot understand other areas in terms of this one. The original area then becomes his basic analogy or root metaphor. ... He undertakes to interpret all facts in terms of these categories. ${ }^{38}$

Victor Turner uses the concept of martyrdom as a root metaphor for illuminating the social drama between Thomas Beckett, the Archbishop of Canterbury, and Henry II, the King of England. ${ }^{39}$ Sherry Ortner, on the other hand, classifies root metaphors as belonging to the category of elaborating symbols, and asserts that root metaphors are symbols with "primarily conceptual elaborating power, that is they [root metaphors] are valued as a source of categories for conceptualizing the order of the world". ${ }^{40}$ Ortner further suggests another type of elaborating symbol - key scenarios, which are defined as having "primarily action elaborating power; that is they [key scenarios] are valued as implying mechanisms for successful social action". ${ }^{41}$ A careful reader here might have noticed a discrepancy between Turner's and Ortner's approaches. Whereas Turner situated martyrdom as a root metaphor, in Ortner's perspective the path of martyrdom that Thomas Beckett chose in order to "win" over Henry II would be a key scenario, for martyrdom provided Thomas Beckett with a

35 O. F. A. Meinardus, Coptic Saints and Pilgrimages..., 26.

36 Here, I specifically talk about suffering for Jesus Christ that is suffering resulting from persecution on the basis of one's Christianity.

37 In this context, I use Sherry Ortner's discussion on the topic; see Sherry Ortner, "On Key Symbols", American Anthropologist 75/5, 1973, 1338-1346.

38 Pepper quoted in Victor Turner, Dramas, Fields, and Metaphors: Symbolic Action in Human Society, Ithaca, NY: Cornell University Press 1974, 26 (emphasis retained in the original).

39 V. Turner, Dramas, Fields, and Metaphors...

40 S. Ortner, "On Key Symbols...", 1340.

41 Ibid. 
recognized pattern of social actions leading to a certain result. Leaving the imparity of definitions aside, allow me to discuss saints in Ortner's terms. As suggested above, suffering/persecution can be seen as constituting a root metaphor in Coptic history, with the lives of saints providing key scenarios for meaningful social action. The following discussion will focus on an ethnographic account demonstrating in more detail what is meant by the key scenario and how saints' lives are imparted as forma vitae, i.e., a life to be reproduced.

\section{Saints as examples and exemplars}

In the enlightening article "Exemplary Series and Christian Typology: Modelling on Sainthood in Damascus" Andreas Bandak discusses the way saints (and other models) and their lives are posited as examples and exemplars to be followed and emulated in the devotional movement of Our Lady of Soufanieh in Damascus, Syria. ${ }^{42}$ Bandak explores the relationship between examples, exemplars, and exemplification, and contends that while an example (i.e., a particularity/sample) points to a single instance, an exemplar indicates a model (i.e., universality) to be followed and replicated. ${ }^{43}$ Saints and the way they are utilized in sermons, Bandak argues, are made both - i.e., samples and models - at the same time. ${ }^{44}$ In fact, he argues "that the Bible, more than being mere letters read and used in social contexts, is a web of exempla, of figures to imitate and reflect upon". ${ }^{45} \mathrm{In}$ other words, people, their lives and deeds described in the Bible, according to Bandak, serve as templates for followers to mold their life and character.

Saints and their lives are used comparably in Coptic Orthodox Church teachings about Christianity. During one interview, Sophie asserted:

... these people [saints] were normal people, as we are. They were not extra powerful. They were tried with every trouble we are having: they were sick, they had a lack of money, they had a lot of wishes and desires, they had families to take over, they had

42 A. Bandak, "Exemplary Series and Christian Typology...".

43 Here, Bandak mentions Jacques Derrida's distinction between two meanings of an example, a sample (example) and a model (exemplar). In my view, the distinction is similar to the famous Geertz's one between a "model of" and "model for", something Simon Coleman concurs with - see Simon Coleman, "Anthropological Tropes and Historical Tricksters: Pilgrimage as an 'Example' of Persuasion", Journal of the Royal Anthropological Institute 21/S1, 2015, 144-161: 159, note 2.

44 A. Bandak, "Exemplary Series and Christian Typology...", 53.

45 Ibid., 54. 
everything that was there. But their way of doing things with God, allowed them to reach these things. ${ }^{46}$

In other words, although saints are positioned on the same level as believers they are also placed as role-models for people to follow and emulate. The saints were just like anybody else, faced with the difficulties we face, yet attained holiness anyway - we can see that in this way the agency of the Self is challenged to transform and to achieve holiness too. In this context, it is telling how one Sunday School session (the first one I attended), for girls between 10 and 13 years, was conducted. In the lesson, the girls learnt about the lives of Saints Maximos and Domadious. Yet, as the teachers were narrating the story, they constantly interrupted their narration and prompted the girls to find comparisons between Maximos' and Domadious's lives and the girls' lives. For a time, the poor foreigner for whom such a lesson style was utterly alien was lost - were we talking about Maximos and Domadious or us? It was impossible to tell. The interruption of the story and the subsequent continuation of the story were so seamlessly worked into the flow of the lesson that it took me a while to recognize who it was we were talking about. ${ }^{47}$ The next section will describe in ethnographic detail the Sunday School lesson, illustrating closely my earlier arguments about a key scenario, examples, and exemplars. ${ }^{48}$

Before one of the teachers started narrating the story, she emphasized that in this story it was important to realize how "we should deal with siblings and how to deal with each other; we should teach smaller [younger] siblings the prayer and then pray together, just as Maximos and Domadious did. Yes, they prayed together." The following text is a depiction of the lesson: ${ }^{49}$

46 Interview with Sophie, 28 January 2003. Sophie is a volunteer Sunday School teacher serving, in fact, in two Cairo Sunday Schools. She is in her late twenties and single, I believe. She works in an administrative position. Sophie's help and knowledge about the Church and miracles were most helpful when I seemed to be lost. It was because of our conversations that I realized the intimacy and reality of the relationships between Copts and their saints.

47 Interestingly, from what I could see during other lessons and other Sunday Schools, this is the pattern and the way teaching proceeds and so everyone, except me, knew exactly who we were talking about and where in the story we were.

48 The following section is based on my participant observation at the Sunday school on 7 February 2003.

49 For the reader's convenience and clarity, though ultimately depriving him/her of the bewilderment I experienced, I have put the description of Maximos's and Domadious's lives in italics (not having it word for word) and I have left the teachers' talk to the girls in normal font, using quotation marks to suggest when someone speaks. 
Maximos and Domadious were sons of a king and decided to become monks but they did not want to tell their father, ${ }^{50}$ so they told him instead that they wanted to go to a monastery to see it and to pray there. Their father agreed and in order to ensure their safe return, he sent an army with them. At the monastery, Maximos and Domadious sent the army back saying that they would stay for little while, but they became monks instead and went to a monk Achabius in el Sham area [Syria]. Before they reached him, Achabius had a dream of Makarios telling him that after he [Achabius] dies Maximos and Domadious should go to the Makarios Monastery in Egypt. The moral of the story so far is that God will always reward you if you choose him.

The story is suddenly interrupted and Dalia [one of the teachers] asks what Maximos and Domadious left behind. The girls do not know, but then one of them says "food". "Yes," and Dalia helps the girls, "the royalty". Some other girl says "the family"; "yes," and Magda [the other teacher] helps again saying "everything". Then Dalia continues: "The saints who were originally kings left many things behind them, but God rewarded them and gave them fame. He gave them the gift of curing diseases." Sick people heard about them and went to them, so that the saints could perform miracles to cure them. "But we, simple people, what can we leave behind?" "TV," says one girl. "Helwa [very nice]," responds Magda and although other suggestions come, she returns to the topic of TV and asks: "So for example if there is the last episode of a soap opera that you are watching, but at the same time there is a Mass in the church. What will you do? But honestly!" The classroom bursts out with laughter. But the girl does not give in and asserts: "I'll make a compromise: I'll watch the episode and then go to church." That elicits more laughter, but Magda says: "No, we cannot make compromises, we cannot choose the middle road, we have to stick to something." Yet, the girl retorts that although she likes reading the Bible by herself, she gets bored when the priest talks. Magda says: "I myself get bored sometimes, but even if we only listen, we can hear something that can change us, depending on our spirit, for example when Anba [i.e., Bishop] Antonius went to church and he heard this one verse, his life changed completely."

... Then, again, Dalia picks up the story and continues with the narration. The story seems to jump to a moment when Maximos and Domadious sailed back to their homeland, and the captain of the ship put their names

50 The implicit assumption here is that the father would not allow them and there are many contemporary stories that correspond to this. During my fieldwork I stayed in a convent, and one of the nuns entered the convent in a similar manner, i.e., in a covert way, hiding the fact from her mother, who, when she was eventually told, cried and cried. 
on his boat. A servant of the king - of Maximos's and Domadious's father - saw these names and remembered Maximos and Domadious, so he went to the captain to see if these names belonged to the king's sons. The captain told him that these were two great saints, and that their names protected the ship from storms, and so on. So, after the servant further determined that these names indeed referred to the Maximos and Domadious that he used to know, he went to the king to tell him. The king was very happy to have found his sons, and because he wanted them to come back home, he sent the Queen, their mother, and their sister to bring them back, because they could plead with Maximos and Domadious more than he could. The Queen and the princess pleaded very much with Maximos and Domadious, but having made their decision to become monks, they persisted, and sent their mother and sister back. Now, at that time, the Pope of Rome died and people wanted either Maximos or Domadious to become the next Pope. Maximos and Domadious thought a lot about the decision. And their father, the king, was very happy, because this seemed to be the only way he could have them close to him. But then Maximos and Domadious recalled Achabius' dream that after his death they should go to Egypt. So, they took counsel with each other, and tried to decide together on their next action.

"Do you, girls, do the same? We should always consider the opinions of others. Suleiman, who was very wise, always considered the opinions of others." At this point, the girls ask who Suleiman was, but Dalia, who made the comparison, does not know, so Magda intervenes saying it was someone from the Old Testament. "In any case, the moral point here is that we should ask older people for advice, especially older siblings, but even when they are younger, because they can advise us."

So, secretly, Maximos and Domadious took a boat to Egypt, but on the way, they became hungry and thirsty, so God made the salty sea water drinkable, and later during a storm a cloud descended on the boat and took Maximos and Domadious to Egypt [to the Makarios Monastery]. There they decided to stay in a cell for three years, and every day they went to church, very quietly and spoke to no one. Dalia, at this moment, emphasizes the fact that they went very quietly.

At that moment, a girl asks whether they went for communion every day, which Dalia confirms and declares that at that time there was church every day. "But it is not important, the important thing is that they went very quietly and did not speak to anyone."

But people noticed them and were curious who these two monks were who were so quiet and who always came to church and then quietly left. Makarios was also curious, but he could not catch them and talk to them, so he went and slept in front of their cell, so in the morning when Maximos 
and Domadious would go to church, he would be able to talk to them. In the middle of the night, Makarios woke up and saw Maximos and Domadious praying and as they were praying, he saw a beam of light coming from their mouths pointed towards the heaven. Although there were devils all around the beam of light, they could not enter it. So Makarios understood that they were talking directly to God, and that was the reason they did not speak to anyone. Thus, he just asked them to pray for him, and left them there. Then, sometimes afterwards, Maximos died and Domadious was very, very sad and died three days later. And they perform miracles even today.

At the end, Dalia asks: "What is the secret of their power?" And immediately she answers herself: "They sacrificed royal fame, so God made them famous as saints, God helped them because they knew the way and were modest. And this can happen to us as well, we shouldn't be proud of ourselves."

I hope that from the description the reader is able to see not only the dynamics of the session, but also the way saints' lives are appropriated, made relevant, and fitted to the lives of contemporary Copts. The parallel between the lives of Maximos and Domadious, in our case, and the girls' lives is drawn as a matter of fact, as if the girls' lives were very similar to those of Maximos and Domadious. We can see that, on the one hand, Maximos and Domadious are posited as examples, as just instances of ordinary people, and that, on the other, they are situated as exemplars their lives function as templates for the girls to follow and imitate. Further, following Bandak's argument, the girls through such guidance are positioned as links in a chain connecting them to the saints (and consequently to God). ${ }^{51}$ In other words, they are situated as part of the same series as the saints, forging an inherent relationship between the past (be it figures, events, etc.) and the present, all tied to the divine (God). Bandak points out that during such occasions (as my Sunday School session or his sermons) positioning people in seriation (as he calls it) implies that "people are placed in a particular time-space whereby personal change is tied to God's planning and human response", 52

The agency of the girls is challenged and transformation of their selves is explicitly advocated - notice the moral points entwined into the lesson: "they prayed together", "we should always consider the opinions of others", "they knew the way and were modest", "we shouldn't be proud of ourselves". The task which the girls got for the week - to gather other

51 A. Bandak, "Exemplary Series and Christian Typology...”, 52. Simon Coleman and Joel Robbins make similar point: see S. Coleman, "Anthropological Tropes...", 145149, and J. Robbins, "Ritual, Value and Example...", 20-22.

52 A. Bandak, "Exemplary Series and Christian Typology...", 52. 
siblings and pray together because "siblings should do things together" and then "you'll see how the whole house will become peaceful and nice" - fosters the development of a distinct Self that accommodates the values promoted by the Church. In summary, the saints are identified as the embodiment of social values which the girls are actively encouraged to emulate by adopting explicitly specified virtues and by engaging in approved social action, with the saints serving as both examples and exemplars. ${ }^{53}$ The saints' lives become forma vitae, and in terms of the last section, their behavior and deeds provide key scenarios, i.e., patterns of social actions leading to a socially approved and/or desired outcome.

Additionally, the way the miraculous is woven into the story portrays the link between saintliness and holiness, and the tacit importance miracles enjoy. Maximos and Domadious are not "very well-known" saints for performing miracles. We can see that miracles were neither the point of the story, nor so spectacular that the girls would focus on them. Yet, I suggest that the miraculous is integral in relating the holiness of saints, as can be seen from remarks such as: "God rewarded them [Maximos and Domadious] and gave them ... the gift of curing diseases. Sick people ... went to them, so that the saints could do miracles to cure them", or from the comment made at the end of the Sunday School lesson: "And they perform miracles even today." These statements imply that their performance of miracles attests to their "saintliness". As already pointed out, the miraculous is a sign of holiness; it is perceived as evidence of it and thus essentially linked to sanctity. Nevertheless, the miraculous is also connected with molding the girls' selves, as the teachers observe: "The moral of the story so far is that God will always reward you if you choose him." Or, as Dalia's last commendation states: "God helped them [Maximos and Domadious] because they knew the way and were modest. And this can happen to us as well, we shouldn't be proud of ourselves."

In fact, although theologically martyrs are positioned as more important than other saints, I submit that, socially, saints performing miracles (who could of course be martyrs) are more important to people as these comply with people's intercessions and serve to legitimize and authenticate their faith. As I have argued elsewhere, miracles serve as an important bound-

53 Notice that the narrative provides in a subtle way, a possibility of defying parental authority. Maximos and Domadious did not tell their father of their intention to become monks, because their father would not allow them. Ultimately, from the point of view of the Church such an attitude is selfish on the part of the father, though understandable (from parental perspective), and the story in a way provides a precedent for such a behavior. However, I would like to stress that it is very clear (from other contexts) that it is possible and laudable only when a person decides to devote her/his life to God and is adult. 
ary marker between the Orthodox Church and the "Other", and saints constitute an integral part of this differentiation as it is generally "their" miracles that mark the identity of the miraculous as a Coptic Orthodox one. ${ }^{54}$ The fact that the wonders performed by saints are of utmost importance to the Church is openly acknowledged by the Church, as Abuna Rahib's following remark suggests: "The miracles of saints support our faith and our principles of the Coptic [Orthodox] Church." 55

Similarly to suffering and persecution, the significance of the saints and their miracles for the Coptic Orthodox Church is not a contemporary issue, but is historically formed. The History of the Patriarchs of the Egyptian Church, in the seven volumes that I managed to locate (covering the period from 849 to $1894 \mathrm{CE}$ ), describes each period in terms of the presence or absence of persecution by each ruler, and focuses on enumerating the suffering and troubles each Patriarch faced, the saints and martyrs each period witnessed, and the miracles that occurred. ${ }^{56}$ In fact, one of the most momentous events in Coptic history is the miracle of moving the Muqattam Mountain in Cairo. The miracle happened during the reign of $\mathrm{Al}-\mathrm{Mu}$ 'iz $\mathrm{Li}$ Din-Illah the Fatimid, who was fond of intellectual and religious exchanges, and resulted from a challenge issued to the Coptic Pope by the Caliph or his vizier or a Jewish rabbi (depending on the version) to move the Muqattam Mountain. ${ }^{57}$ This trial was based on a verse from the New

54 M. Šebelová, "The Miraculous and Coptic Orthodox Christianity...".

55 Interview with Abuna Rahib, 9 February 2003. Abuna Rahib is a priest responsible for youth in his diocese in Middle Egypt. He is in his fifties, with a very responsible attitude towards my research.

56 There seems to be a difference in the nature of reported miracles in the History of Patriarchs, i.e., there are many reports on icons weeping and other object-related miracles. However, the point here seems to me to be the occurrence of miracles and importance of the saints, and not the change (if there is one) in the content of miracles in the history of the Coptic Orthodox Church, perhaps a topic for another research project. In this article, I use only the second volume of the History of the Patriarchs: Sāwīrus ibn al-Muqaffa', Bishop of el-Ashmunein, History of the Patriarchs of the Egyptian Church: Known as the History of the Holy Church II/2, trans. Yassā 'Abd al-Masīh Khs-Burmester, O. H. E, Le Caire: Société d'archéologie copte 1943.

57 I have heard this miracle from many people (especially Cairenes) and in the account offered here I rely on their versions, on the version provided in the brochure The Biography of Saint Samaan (The Church of Saint Samaan the Tanner in Mokattam, The Biography of Saint Samaan the Shoemaker "the Tanner", Cairo: The Church of Saint Samaan the Tanner in Mokattam ${ }^{2}$ 1998) and on the report in the History of the Patriarchs (S. ibn al-Muqaffa', History of the Patriarchs... II/2...). In the versions which I encountered the scheming was done either by a malicious Muslim vizier (a convert from Judaism) or by a Jewish rabbi. Heo, in her version of the miracle, reports that when Caliph learnt about the verse from the Bible he issued the challenge without mentioning anyone else (A. Heo, The Political Lives of Saints..., 96). On a captivating account of the relations between the Coptic Orthodox Church and Israel, see ibid., 77-103. 
Testament in which Jesus Christ says: "If you have faith as small as a seed of mustard, you can say to this mountain "move from here to there' and it will move. Nothing will be impossible for you" (Mt 17:20). If the Patriarch was not successful and did not move the mountain, the Copts were to choose one of the following three options (as their faith would not be proved): convert to Islam, leave Egypt, or be killed. The Pope being troubled by the request asked for a three days delay, and went to pray and fast in the Hanging Church (the Suspended Church) of the Virgin Mary. There he dreamed of the Virgin Mary, who directed him to encounter a man called Samaan the Tanner, who after much pleading advised the Patriarch to serve the Holy Mass at the base of the mountain together with all the Copts, to cry out loud Kyrie eleison ("Lord, have mercy") many times and then to prostrate themselves three times, making the sign of the cross over the mountain before each prostration. And, indeed, every time the Pope made the sign of the cross over the mountain, the mountain was lifted, so that the sun could be seen underneath it, and it moved and when the Pope and people prostrated themselves, the mountain came down. The mountain was lifted up and came down three times after which the Caliph cried out loud: "Enough, Patriarch, I recognize the correctness of your faith, God is great, may His name be blessed."

The narrative of moving the Muqattam Mountain partially illustrates the way Copts conceive of the surrounding world, a manner even more marked in written documents such as the History of Patriarchs and The Biography of Saint Samaan. The latter defines the request to move the mountain as a result of a "plot devised to destroy the Copts altogether", 58 the demand itself is an "ordeal" sion one that befell all Copts), while the former specifically talks about the incessant lament of the Pope, and his great fear that came upon him when he heard the Caliph's request. This goes back to my earlier argument about the significance of suffering and pain positioned as a root metaphor in the Coptic Orthodox worldview. I suggest that the History of Patriarchs (and to some extent The Biography of Saint Samaan) is, in fact, conceived in terms of this root metaphor (i.e., in terms of difficulties that each Patriarch underwent). In other words, the Patriarch's fate is depicted as an embodiment of suffering and persecution and by extension of the whole Church, i.e., the Christian community, since the Patriarch, the Coptic Orthodox Church, and the Coptic community are conflated into one. This conflation in one sense becomes more understandable if we recall that although the official title of the Patriarch in Arabic is Anba (Bishop), he is more fre-

58 The Church of Saint Samaan the Tanner, The Biography of Saint Samaan..., 48.

59 Ibid., 52. 
quently than not called Abba or Baba (father). The Patriarch is thus explicitly situated as father of the whole Coptic community and his lot is equated with that of the rest of the "family". Being the head of the family, the Patriarch becomes the symbol, the personification of Coptic Orthodox Christians. Although the History of Patriarchs mentions, for instance, Christians who served as secretaries to Khalif Ahmad ibn Tulun (and thus had to have some assets as well as power), their circumstances are not elaborated upon nor considered. ${ }^{60}$ However, through miraculous events, such as moving the Muqattam Mountain, Copts are able to overturn and expose the persecution (the root metaphor) and although they are victims of discrimination, they are ultimately victorious. Here, we can also recall the words of the late H. H. Pope Shenouda where he asserts that the more suffering (for the Lord) a believer undergoes, the more glory awaits him/ her. ${ }^{61}$ In other words, increased human (i.e., finite) suffering means increased eternal glory. This way the miraculous plays an indispensable role in the root metaphor, as it ensures the ultimate triumph (i.e., salvation), provided the key scenario is followed by the Self, i.e., the Self is appropriately formed by emulating an approved social action.

So far, we have seen how vital and essential saints (and their miracles) are in the constitution of social values, the proper Self, and appropriate social action, and how through the Church's teaching, the saints and people constitute links in a chain forming attitudes towards and an understanding of past figures and past events. In the following section, I will focus on an ethnographic portrayal of individual relationships between saints and Copts, with the aim to demonstrate how temporal distinctions are broken and how saints represent an actively experienced contemporaneous component of a lay person's life.

\section{The relationship between people and saints}

Relationships between a saint and a person are formed from early childhood. As the description of a Sunday School session above suggests, the Church actively encourages children to form such relations and it is rare to find a pupil or a student not dedicating each subject in school to a saint (randomly assigned), so that the saint can look after it. The student still has to study hard and prepare for school, but assigning a saint to a subject ensures fair treatment during grading, or on occasions that are beyond the control of the student. The saints, then, play a crucial but also everyday

60 "Ahmad ibn Tulun had two secretaries (who were) brothers, one of the two of them was called Bessus (Basus) and the other, Abraham (Abraam), sons of Moses (Musa). He loved them both ..." (S. ibn al-Muqaffa“, History of the Patriarchs... II/2..., 105).

61 H. H. Pope Shenouda III, Words of Spiritual Benefit II..., 103. 
role in the quotidian life of ordinary people. Van Doorn remarks that saints form an indispensable component of a devout Copt's life. ${ }^{62}$ According to her and my fieldwork, life without saints is unimaginable for a believing Copt, as they accompany him/her from early childhood and his/her universe is "filled with saintly holiness and blessings". ${ }^{63}$ Saints advise and comfort people; they provide support in everyday life, help in times of need, and are an essential feature of a person's spiritual life. In this way, people are able to establish very personal relationships with saints, for saints, as Gabriela put it, are without limits and thus they are more perfect than human friends. ${ }^{64}$ Similarly, my other two research participants, Abuna Rahib and Sophie, stated:

Saints are very near to the alive members. The body of Jesus Christ consists of alive and dead members. We cannot forget them at all; we mention them in our prayers, liturgy, private prayers, and many people live in friendship with saints. ... Saints have power to help us, as well as Jesus Christ, as they have many abilities to help us. They became free from all trouble that we face now. Besides, Jesus Christ, Himself, ordered us to respect them and to behave towards them with reverence. 65

... our belief is that they [saints] are not really dead. Death is just a transfer of a place, although we cannot see them with our eyes now, they are still alive all around us. [It is] like the microscope, with your own eyes you cannot see the, whatever you can see under the microscope, okay? Saints are the same thing, they are not present with body that we can touch and feel, but they are alive with another body. ${ }^{66}$

As we can see, saints are then posited as living and not dead. This perception is based on the Orthodox Church's division of its members into the Church Triumphant, composed of the invisible souls residing in Heaven, and the Church Militant consisting of human beings alive in the "mundane" world. While the body eventually dies, the soul lives on and if the person concerned is a saint then she/he can intercede on other people's behalves and perform miracles. ${ }^{67}$ This way, saints, as members of the Church Triumphant, constitute a fundamental part of the structure of the Coptic Orthodox community and are able to mediate between Heaven

62 N. van Doorn, "The Importance of Greeting the Saints...".

63 Ibid., 115.

64 Personal communication with Gabriela, February 2003. Gabriela is in her early twenties, single, from Middle Egypt. She was instrumental in my research, enthusiastic about my project and to her I owe much. Gabriela serves as a Sunday school teacher for high school girls, and describes herself as close to the Church. In her civil job, she likewise works as a teacher, and in my view has a natural bent for it.

65 Interview with Abuna Rahib, 9 February 2003.

66 Interview with Sophie, 28 January 2003.

67 Ordinary Copt's soul resides in Hell or Heaven according to the merit without the ability to mediate or intercede. 
(God) and earth (the Church Militant). ${ }^{68}$ The unity of the Church Militant and the Church Triumphant is explicitly recognized, and as Abuna Istafarus emphatically put it: "Not even death can separate us from the Church." 69

The relationship between an "alive" person and a saint can enter hagiography as, for example, in the many stories about the friendship between Mari Mina and Pope Kyrillos when he was still alive. Yet, what I would like to stress in this context is the intimacy of the relationship between a saint and an ordinary person. Karima, a research participant who describes herself as being far from the Church, talks with longing about her vision/ dream in which the Virgin Mary visited her and held her hand, after what was more than an unpleasant incident. In her words "psychologically it [the communication with saints] moves me from one status to another, it makes me happier, calmer, more relaxed". ${ }^{70}$ In a very different context, Thorbjørnsrud asserts that pictures of saints provide a feeling of protection and facilitate communication with the saints:

Alice the housewife, for example, says that she likes to have such pictures in every room in the flat, because she then feels that she can keep in constant contact with the saints. They can keep an eye on her, and she on them, and she says that she frequently has small conversations with them while cooking or cleaning. To her this represents a great comfort. ${ }^{71}$

Later, Thornbjørnsrud reports a dream of one of her research participants, Christin, in which the Virgin Mary advised her to break off her engagement, which Christin eventually did. ${ }^{72}$ In other words, the relationship between a person and a saint is often shaped according to relations between two humans and in line with human experience. Saints are not distant figures, but the miraculous narratives portray them as very human who can even be mischievous as the following story (about Anba Wanas, a child saint) implies. The emphasis of the story is not placed on the miraculous cure but rather on the human (childish) nature of the saint.

68 I am grateful to one of my reviewers to point that out.

69 Interview with Abuna Istafarus, 25 January 2003. I met Abuna Istafarus in Middle Egypt where his church is located. He belongs to a younger generation of priests, and in my estimate, he is in his late thirties. Abuna Istafarus was very enthusiastic about miracles, and more than ready to talk about the miraculous, taking it very seriously, trying to make me understand the discourse.

70 Interview with Karima, 6 February 2003. Karima lives in Cairo and is in her early forties. Although once close to the church, nowadays she very definitely tries to maintain a distance from it. At the same time, she was extremely helpful in my research.

71 B. Thorbjørnsrud, Controlling the Body to Liberate..., 164-165.

72 Ibid., 186. 
Fayza was paralyzed and she could not move her legs and hands. She went to see many doctors and each told her something different. Then her brother told her that she needed to pray to Anba Wanas. So they brought her to Anba Wanas church, and put her next to his body and covered her with the red velvet wrapper. They gave her hanun [a piece of bread] and she ate it and fell asleep. In her dream, she saw Anba Wanas, who told her to rise and help him to clean the church. So she did and during the cleaning, she found a golden ring. She showed it to Anba Wanas, who told her to put it in the donation box. So Fayza tried, but the ring would not go through, one half was too big. She turned to Anba Wanas for help, but he was laughing at her effort, and she understood that he was just kidding her when he told her to put the ring into the donation box. Soon afterwards she woke up and she was cured. ${ }^{73}$

The friendship between a saint and a person can begin in many ways, be it by the saint performing a miracle (if a saint performs a miracle for a person, they are likely to become friends), by attending services in a church associated with a particular saint, or by having a vision, etc. Furthermore, Sophie suggested, the more one tries to learn about a saint, the more the saint will try to get in touch with him/her. ${ }^{74}$ Van Doorn reports that developing a friendship with a saint is perceived as more than desirable and, in this context, she quotes Ammonius, Bishop of Luxor, as saying that a saint is "like a friend who knows God better than you do, and whom you can more or less ask to introduce and recommend you to God". ${ }^{75}$ According to van Doorn, some people try to develop a friendship with a saint by special prayers, or seek advice on how to "befriend" a specific saint from the heads of an adiora (a monastery or a convent) dedicated to a particular saint. Additionally, a saint can be concerned with an area she/he is associated with. Van Doorn quotes someone from Fayum as saying: "There is no Christian family in Fayum that does not have a relationship with Anba Abra'am."76 In a like manner, I documented the following narrative related to the late Anba Athanasius, a Metropolitan responsible for the Diocese of Beni Suef and Bahnasa:

73 This narrative is taken from a brochure about Anba Wanas in Arabic, loosely translated for me by Youannen (personal communication, October 2002) who at the time of my research lived in Cairo, was in his mid-twenties, was single, and worked as a computer lab technician, although originally a designer. He is an Orthodox Copt, but because his close friend started to attend Masses in a Protestant church and basically turned away from the Orthodox Church, Youannen was confronted with the Protestant faith, and started to search and learn more about the Coptic Orthodox and Protestant Churches. He sometimes attends (only because of his friend) the same Protestant Presbyterian church Mass where I had conducted research previously. Youannen was instrumental in this project as he enabled me to meet with other people, interpreted for me, searched for information, and, fortunately for me, became very involved with the project.

74 Fieldnotes, January 2003.

75 N. van Doorn, "The Importance of Greeting the Saints...", 108 (interview from 15 February 1989).

76 Ibid. 
A husband and wife were arguing together, they were fighting for a long time and it was getting increasingly serious, but Abuna in their church [belonging to the Diocese for which Anba Athanasius was responsible] was not able to solve it. Then one night Anba Athanasius appeared in the husband's dream and said: "You embarrass me in front of other saints and in front of Jesus Christ [by your behavior]." And the man, from the next morning, immediately improved his behavior. ${ }^{77}$

In other words, Anba Athanasius expressed concern over the behavior of one of his former congregation members, who in turn paid heed to him and changed his actions. The story also indicates the union between the "alive" and "saintly" members of the Church, or put differently the unity between the members of the Church Militant and Church Triumphant. In fact, saints are expected to express concern and "look after" people. In cases where they fail to do so or, more precisely, where a person feels that a saint failed to do so, a fight or a dispute between a person and a saint is likely to ensue, as for example in the following narrative, recorded by Ranya AbdelSayed:

A man working as an accountant in a governmental job went to Mass one morning. Since there were no available parking spaces near the church he had to park further away. Upon his return, he found that his car had been stolen along with some workrelated accounting books that were inside. Of course, he became very upset and after reporting the theft to the police, he went home. And there he spoke angrily to a picture of Anba Abra'am, reproaching him on how he [Anba Abra'am] could have let this happen to him [the man], especially after having served as a deacon in the church. At the end of his tirade the man flipped the picture face down on the table and left it there like this. The next day at work, his manager was naturally very upset about the loss of the books, and since the man, at that time, was only three years from his retirement, the whole event was a big embarrassment. One or two days later, the man went to the church again, but when the priest asked him why he was not dressed to serve at the altar, the man answered that it was because he would not be taking the Holy Communion, and cited as a reason his dispute with Anba Abra'am. The priest convinced him that this was ultimately wrong (which the man knew anyway), that he needed to take Communion and apologize to Anba Abra'am, and that the car would be returned. ${ }^{78}$ And so the man took the Communion, and when he went home, he apologized to Anba Abra'am, and flipped his picture back to the correct position. ${ }^{79}$ The next day, his car was found with all the accounting books inside, though without the stereo. ${ }^{80}$

77 Fieldnotes, February 2003.

78 Here, the man noted that he had never told the priest that his car had been stolen, he simply stated that he was upset with the saint thus drawing the attention to the second sight (shaffafeya) which the priest displayed.

79 It is worth pointing out here the power of authority priests carry. We are talking about a middle-aged man, three years from retirement from a governmental job, yet who listens and meekly does as the priest bids him.

80 Personal communication with Ranya AbdelSayed, March 2003. 
Saints indeed constitute the same community as other Copts, and this is true not only from a theological perspective. They comfort people, help them, advise them, support them, but can also make people upset or angry, even to the point of threatening them with alienation. Saints are looked up to in times of distress and in times of joy. In brief, they are companions and friends whose presence is experienced frequently. Since saints seek communication with ordinary people, it is only up to the people to prove that they are worthy of the communication. For instance, Gabriela, after my expression of puzzlement at the relationship between people and saints, made the following remark: "The relationship between people and saints depends on their [people's] spiritual level. If they are close to God, you cannot not feel them."

In other words, saints are viscerally experienced as indisputably present. The close relationships which Copts develop with their saints thus not only constantly remind Copts of their comportment (challenging it on occasions), but also, similarly to the girls in the Sunday School lesson, this relationship links them to the saints while they share the same temporal plane and often times share the same space (as in the case above of Alice and pictures) and thus they experience life together. Through key scenarios and the production of time when saints are experienced as actively present in someone's life, people are able to re-live/re-enact events found in the Coptic Orthodox past. An encounter with the miraculous and a feeling of close attachment to a saint enables a believing Copt to experience the world in the same way as the saint did and re-live the past. The following section will elaborate on these statements, focusing on the theological concept of tradition which underlies the experience of being in time and being with others discussed in this part. In this way, I will explore the Coptic disposition towards the past.

\section{Saints, tradition and history}

Due to the existing socio-political context in which Copts find themselves, Coptic Orthodox role and experiences are rather missing from the official Egyptian historical discourse. ${ }^{82}$ This public invisibility, as Berit Thornbjørnsrud calls it, is largely resented by Copts (though also accepted as inevitable) and the Church, she points out, is heavily involved in the construction of Coptic Orthodox historical narrative by prolific use of Internet, and by producing videos, pictures and stickers. Yet this interpretation of history, Thornbjørnsrud observes, is not done in academic terms

81 Interview with Gabriela, 18 February 2003.

82 B. Thorbjørnsrud, Controlling the Body to Liberate..., 67-69. 
but rather in teleological ones as the purpose of history is "to reveal what Father Malaty calls the wondrous work of God". ${ }^{83}$

In this section I will argue that the Coptic Orthodox attitude towards the past is molded by a theological concept of tradition which is defined as "the faith once delivered to the saints". 84 The notion of tradition is of crucial theological importance as, according to Father Malaty, the Orthodox faith contains two aspects, the church and tradition, each constituting an indispensable element of faith. He maintains that "the word "tradition" does not mean 'imitation of the past', but it means biblically 'delivering a deposit and receiving it'. A generation delivers the faith and another receives it". ${ }^{85}$ In line with my argument above, tradition thus links past, present and future Coptic generations, establishing seriation (in Bandak's sense) where saints (through being examples and exemplars) serve as constituting elements of tradition; i.e., they received the Faith and deposited it for subsequent generations. Yet, tradition is not defined as "a blind obedience to the past and a mechanical transmission of a passive deposit. ... it is [not] a museum for antiquity" but, on the contrary, tradition is a "living thing". 86

Although tradition is positioned as a transmission of faith, this transmission is not achieved only through the apostles' writings but mainly through the Holy Spirit, who "guided their [apostles'] feelings, attitudes, worship, behaviour and their preaching". ${ }^{87}$ Father Malaty argues that one reason for the authority of the apostles is their eye-witnessing and experiencing of Jesus Christ's deeds and the events of His life. It is the experience that is given emphasis in the Orthodox concept of tradition, but experience by itself is not enough. Tradition has been constituted by the "Holy Spirit who guides the life of the Church, reveals the truth and gives her the unity with God in Jesus Christ". ${ }^{88}$ While this characterization clearly renders tradition a theological concept, anthropologically speaking, the term "practice", i.e., an assortment of concrete rules connected to particular processes of power and knowledge, can be substituted for the term "tradition". For instance, St. Basil the Great (cited in Malaty) sees tradition as crucial to the performance of ceremonies and sacraments; and he asks:

... who is there who has taught us in writing to sign the sign of the cross those who have trusted in the name of our Lord Jesus Christ? What writing has taught us to turn to the East at the prayer? Which of the saints has left us in writing the words of

83 Ibid., 69.

84 T. Y. Malaty, Tradition and Orthodoxy..., 8.

85 Ibid., 7.

86 Ibid., 7-8.

87 Ibid., 8.

88 Ibid., 11. 
invocation at the displaying of the bread of the Eucharist and the cup of blessing? ... and these we derive from unwritten teaching [i.e., tradition]. ${ }^{89}$

St. Basil continues his enumeration of some other practices relying on tradition, but I hope my point is more apparent: on one level tradition transmits, indeed is, practice integral to Orthodox faith. I say integral, for without the (living) practice/tradition the Coptic Orthodox Church would not be what it is. While we can say that beliefs and doctrines influence the person's view of life and the world and his/her approach towards them, practice defines the Orthodox way of life.

As pointed out above, the saints are perceived as ideals embodying the true and real Christian faith in all its aspects and thus are essential because it is their contribution which makes tradition what it is. For instance, St. Basil, cited above, upon inspiration from the Holy Spirit, wrote a liturgy most often used in the Coptic Orthodox Church today. It is the saints' lives, comportment, attitudes, beliefs, emotions, faith, and hagiography which constitutes the reception, deposition, and transmission of the faith and thus tradition. Furthermore, I argue that tradition is part of the Coptic disposition towards the past. Father Malaty says: "Thus, tradition is the living stream of the one life of the Church which brings up the past with all its aspects as a living present, and extends the present towards the morrow without deformation." 90

In this context, Coleman's distinctions of relating to the past and discussing the production of temporalities become useful. In his "Right Now!' Historiopraxy and the Embodiment of Charismatic Temporalities" Simon Coleman points out that charismatic Christianity (or any charismatic practice) involves conceiving of (and indeed making) history in specific ways. ${ }^{91}$ Specifically, he focuses on ruptures in the perception of time for newly converted believers into evangelical Christianity and argues that in their stories of conversion (and/or of healing, speaking in tongues, personal redemption, etc.) we can detect an oscillation between at least two ways of dealing with history (particularly concerning the Christian history). He terms them invoking history, which relates to "the relationship between history and mimesis, [i.e.] between present and past", and making history, which is defined as a "conscious attempt to articulate something new, a kind of "event"". 92 In other words, invoking history is defined in terms of the relationship between present and past - something we could see in the description of the Sunday school session, where history was invoked so that the girls were, through the saints' lives, taught

89 Ibid., 31-32.

90 Ibid., 8.

91 S. Coleman, "'Right Now!' Historiopraxy and...”.

92 Ibid., 434. 
appropriate social values. This disposition is necessary so that believers can be presented with examples turned into exemplars (to follow), yet at the same time the Self is independent of the past, which is conceived of as linear and irrecoverable. However, this irretrievability incapacitates experiencing the divine, locating it outside the reach of the believer.

The second type of construction of the past, making history, however, "involves movement towards the ultimate salvationist and transformative aims of the faith" 93 or, in other words, involves undertaking to transform the Self through the faith to reach personal salvation. This transformation is for Coleman's research subjects achieved through charismatic occurrences when events from the Bible are re-lived and re-experienced as the original incidents. It is this way of dealing with history / the past which is of major concern to Coleman, as it is here where the temporal and physical meet. The performative aspect - the re-experiencing and reenactment of the past - which Coleman emphasizes fully resonates with the Orthodox concept of tradition as outlined above, where the past is brought to life in the present through the tradition, but in such a way that the past becomes a living present, not an extinct past. In the context of the Coptic Orthodox Church the past is not irretrievable but becomes alive in the present, for example through miracles, as these prove the presence of Jesus Christ in the Church - yesterday, today and tomorrow. Although the tradition of the Church is presented to any visitor as the same one that has been received from the apostles, in the Coptic understanding of the term, this does not preclude changes and development. ${ }^{94}$

Father Malaty defines tradition as at once creative and conservative, and the seeming contradiction is denied on the grounds that these two form a complementary pair: "Tradition cannot be conserved unless it is continually developed. And it cannot be developed unless it takes place on the shoulder of the past." 95 Tradition in the Coptic Orthodox Church is defined as a lived experience (anchored in the experience of suffering) that can be lived again (it is not a historical moment located exclusively in the past), and is directly linked to the past. Put differently, without tradition, a Copt cannot be conscious of the past, i.e., the existence of the past without tradition is meaningless.

93 Ibid.

94 For instance, see the following quote: "The Coptic Church, however, is not only an ancient branch of Christianity, upholding the old age teachings and traditions; the Coptic Church is also a living Church today. Towards the middle of the nineteenth century the Coptic Church begun to undergo phases of new development" (Coptic Orthodox Patriarchate, St. Mark and the Coptic Church, Cairo: Coptic Orthodox Patriarchate 1968, 111).

95 T. Y. Malaty, Tradition and Orthodoxy..., 47. 
We can also see the summation of all my previous arguments - in tradition they all come together: saints as examples but also exemplars with their lives as forma vitae; saints as links in seriation through which they are connected to contemporary Copts (or rather the other way around through which contemporary Copts are linked to them), and also, together with their miracles, saints that are essential in invoking history and making history. Similarly to Coleman's description of his Swedish charismatics' construction of the Christian past, Orthodox Copts (although they would gravely disagree with having anything in common with Swedish evangelical Christians) view the past of their Church not only in terms of history (Coleman's invoking history) but also in terms of tradition (Coleman's making history), for it is in this way that they can "meet with the Church Saints and Fathers, discover their lives in Jesus Christ, their writings, take the blessings of their prayers and enjoy fellowship with them in Jesus Christ ...".96 To meet the saints through tradition is not meant literally nor metaphorically. It is not seeing what they did, but it is to feel what they (saints) felt; it is to experience what they experienced, and to live one's life as they did, and hence feel their presence in one's life. Tradition is not only about remembering, but also about re-living and re-experiencing the same world as the saints did. Or, put differently, tradition (and by extension the Coptic Orthodox Church) is about being in the world. It is in this way that the divine is experienced, and since Orthodoxy is the framework of life, it is seamlessly sewn into the fabric of life.

\section{Conclusion}

In the text presented above I have striven to provide an ethnographic portrait of saints and the way they are positioned in the Coptic Orthodox Church, and consequently to demonstrate how they are made into examples and exemplars at the same time. Throughout the ethnography, the miraculous surfaces as a crucial aspect of the saints whereas the theological concept of tradition (together with saints and the miraculous) proves to be vital for understanding the Coptic relationship towards the past.

In particular, in the first part we see the importance martyrs enjoy as, for Orthodox Copts, they embody the true Christian ideals. I argue that martyrs encapsulate the worldview which Copts hold in general towards the world, framed in terms of suffering, persecution and pain, establishing thus the root metaphor while martyrdom (and other saints' lives) provides Copts with a key scenario of socially approved social action. I also show that although saints are often likened to common people, they are by no

96 Ibid., 51. 
means ordinary, but function as role models whose lives, beliefs, and experience are perceived as worth emulating and their comportment worth following. They are thus examples and exemplars at the same time with their lives serving as forma vitae. Yet, as Robbins reminds us, exemplars do not always prescribe how to act exactly but rather, they serve as an inspiration for the formation of particular values, and thus, social action is not strictly determined but allows for flexibility and diversity. ${ }^{97}$ In any case, from the description of the Sunday school lesson, we can see how the girls are put into a time-space where their agency and selves are linked to saints (and thus to God) and consequently, the girls' response (social action) is challenged to follow/adapt the advocated values. In this context, miracles emerge as connected with the notion of the holy and thus by extension with saints.

In the later discussions, we can observe the close everyday relationships Copts foster with their saints, with saints advising, helping in times of need, and comforting them. At the same time, this intimate rapport together with the experiencing of miracles and with the notion of tradition then makes the recipient of the miracle feel connected with the past that comes alive in the present and has a transformative effect on the Self. This is the similarity I found to Coleman's discussion of invoking history and making history - specifically the performative and transformative effect making history has on the subject in terms of bodily experience. People feel that their experience is the same as the one of someone else in the past, the experience is brought to life, it is re-lived but it is creative at the same time as the Self's agency is empowered. The past, in the Coptic view, becomes a living present and not an extinct past, it becomes alive in the present. In other words, in this way, Copts are able to appropriate suitable events from the Orthodox past and apply them to the present as if they were actually happening now, not in the past; i.e., they re-live the past now in the present.

97 J. Robbins, "Ritual, Value and Example...", 28. 


\section{SUMMARY}

\section{Saints and Tradition in Coptic Orthodox Christianity in Egypt}

Based on ethnographic research, the article explores the position of saints in the Coptic Orthodox Church in Egypt, focusing particularly on the relationship between Copts and their saints, and on the role the saints play in the Coptic understanding of their Church past. I demonstrate that Egyptian Orthodox Copts are encouraged to model their selves on narratives about their saints, and the saints' lives are turned into forma vitae, i.e., lives to be emulated. Further, I show how Coptic Orthodox saints can be considered key symbols, while their lives can be deemed key scenarios with suffering and persecution representing a root metaphor. The saints, thus, embody Coptic Orthodox values, which are socially accessible through ecclesiastical teachings on the appropriate Coptic Orthodox Self. In this way, Copts are made a part of the same series as the saints, and this seriation, as Bandak calls it, authorizes certain social actions, and social agency is thus challenged to follow such comportment (and particular social values). Further, the saints are crucial for understanding the Coptic concept of tradition, an indispensable element of Orthodox faith, as they represent its constituting elements. I point out that tradition in the Coptic Orthodox Church is defined as a lived experience (anchored in the experience of suffering) that can be lived again (it is not a historical moment located exclusively in the past) and is directly linked to the past. I link this understanding of the past with Simon Coleman's notion of historiopraxy to illuminate the Coptic disposition towards the past, and I argue that in the Coptic Orthodox Church the existence of the past without tradition is meaningless.

Keywords: Coptic Orthodox Church in Egypt; saints; miraculous; seriation; historiopraxy; tradition.

Department of Ethnology

MARKÉTA ŠEBELOVÁ

Faculty of Arts

Charles University

marketasebelova@yahoo.com

nám. Jana Palacha 1/2

11638 Prague 1

Czech Republic 